Journal of American Studies, 34 (2000), I, I-22 Printed in the United Kingdom

(C) 2000 Cambridge University Press

\title{
Short Cuts and Long Shots: Raymond Carver's Stories and Robert Altman's Film
}

\author{
KASIA BODDY
}

Asked by an interviewer about the starting-point for his stories, Raymond Carver once commented:

I never start with an idea. I always see something. I start with an image, a cigarette being put out in a jar of mustard, for instance, or the remains, the wreckage of a dinner left on the table. Pop cans in the fireplace, that sort of thing. And a feeling goes with that. And that feeling seems to transport me back to that particular time and place, and the ambiance of the time. But it is the image, and the emotion that goes with that image - that's what's important. ${ }^{1}$

If Carver was interested in moving from the image into narrative, his stories have had a tendency to inspire their readers to translate them back into images. This was initially a critical tendency, as parallels were frequently drawn between Carver's stories and the paintings of Edward Hopper, and the paintings and sculptures of Photo Realists such as Duane Hanson, Richard Estes and Ralph Goings. ${ }^{2}$ But it was not only critics who looked to draw connections. In 1989, for example, Jo Ann Callis used a selection of Carver's poems to accompany her photographs in an exhibition catalogue, Objects of Reverie, while Bob Adelman has produced a book of photographs purporting to represent Carver Country. ${ }^{3}$

Kasia Boddy is a Lecturer in the Department of English, University of Dundee, Dundee DD3 6JD.

1 John Alton, "An Interview with Raymond Carver," in Marshall Bruce Gentry and William L. Stull, eds., Conversations with Raymond Carver (Jackson: University of Mississippi Press, i 990), i 5 I-68 (1 54).

${ }^{2}$ See, for example, Graham Clarke, "Investing the Glimpse: Raymond Carver and the Syntax of Silence," in The New American Writing: Essays on American Literature Since 1970 (London: Vision Press, 1990), 99-1 22; Kirk Nesset, The Stories of Raymond Carver (Ohio: Ohio University Press, i 994), 3 I.

3 The director of the exhibition said of the pairing, "Both artist and poet share the ability to touch the chords of experience and memory through the use of a fragmented 
As well as provoking comparisons with painting and photography, Carver's work has also been frequently adaptated by filmmakers. Many short films have been made from individual stories, and, although Carver was not involved in any of these projects, in 1982 Michael Cimino (best known for The Deerbunter and the far from minimalist Heaven's Gate) approached him to work on a screenplay on Dostoevsky's life. ${ }^{4}$ Together with his wife, Tess Gallagher, Carver wrote a very long screenplay which was published in 1985 , and shortly afterwards, also for Cimino, an unpublished screenplay called Purple Lake, about the rehabilitation of juvenile delinquents. ${ }^{5}$ Neither has been produced. In 1987, when asked about these, Carver said:

I think that every writer wants to do that at least once, to be involved with Hollywood, and all that sort of thing. I went through that time, I did it, and I'm not interested in doing it anymore. ... It was work for hire, and I don't like that. I don't like to have a boss. ${ }^{6}$

Conceived after Carver's death, Short Cuts was director Robert Altman's thirty-first feature film. Altman is best known as one of a group of "talented, stubborn, and prickly" directors who achieved almost moviestar status in the "Hollywood Renaissance" of the I 970 . ${ }^{7}$ After spending

narrative and the evocation of the lingering effects of a particular event. Neither poem nor image are intended to be illustrative of one another, but were chosen because of a shared sensibility and the resonance of a particular selection of poems with a particular group of images" Jo Ann Callis, Objects of Reverie: Selected Photographs, 1977-89 (Des Moines: Des Moines Art Center/Black Sparrow Press, i989), 6. Bob Adelman, Carver Country: The World of Raymond Carver (New York: Scribner's, I990).

${ }^{4}$ Recently, for example, two short films have been based on "Neighbors" - Tropical Fish (1994), directed by Chris Rodley, and Private View (1994), directed by Mika Kallwass for BBC2's Screen Firsts series. "Why Don't You Dance?" was filmed as They Haven't Seen This (1994), directed by Eric Bergen, and "One More Thing” kept its title in Coky Giedroyc's 1993 short for Channel 4"s "Blow Your Mind" series.

${ }^{5}$ Raymond Carver and Tess Gallagher, Dostoevsky: A Screenplay (Santa Barbara: Capra Press, 1985). See also "On the Dostoevsky Screenplay," in William L. Stull, ed., No Heroics, Please: Uncollected Writings (London: Harvill, i 99 I), i I I-1 s. Purple Lake, based on a story by Joann Carelli, was registered on ro September 1984. See William L. Stull, "Raymond Carver: A Bibliographical Checklist," American Book Collector, 8: I (Jan. I987), I 7-30 (25).

${ }^{6}$ Kasia Boddy, "A Conversation with Raymond Carver," in Conversations with Raymond Carver, $197^{-203}(202-3)$.

7 David Thomson, America in the Dark: The Impact of Hollywood Films on American Culture (New York: William Morrow \& Co., 1977), 238. Among others, Thomson discusses Arthur Penn, Sam Peckinpah, Peter Bogdanovich and Terrence Malik. He describes Altman as "possibly the most pretentious of current American directors" 239. See also Michael Pye and Lynda Myles, The Movie Brats: How the Film Generation Took Over Hollywood (New York: Holt, Rinehart and Winston, 1979). 
most of the preceding ten years working in television, Altman achieved great critical and commercial success with $M^{*} A^{*} S^{*} H$ (1970), a success which he was quick to exploit. "With an acumen that is so far unmatched in contemporary Hollywood," he set up his own production company, Lion's Gate Films, and for eleven years proceeded to make his own films. ${ }^{8}$ Most were commercially unsuccessful, with only Nashville (1975) reviving his standing within the industry. Once again, however, this success was short-lived. Altman was forced to sell Lion's Gate in I98 I and during the eighties found himself working for the studios and in television again. In 1990, he regained critical acclaim with Vincent and Theo and backed that up commercially with The Player (1992), which he described as his "third comeback." In 1990, Paramount had financed Altman to write a screenplay of Short Cuts with Frank Barhydt, but the studio rejected the final script. Following the success of The Player, however, its producers, Avenue Entertainment, agreed to go ahead with the project. As the film intended to "cement" his Hollywood comeback, Daniel O’Brien argues, "Short Cuts could scarcely be more risky," but it was a project that Altman had wanted to pursue for several years. ${ }^{10}$ By interweaving nine Carver stories (with one Altman/Barhydt addition) into a complex single narrative, Altman was returning to the structure and style of his greatest success, Nashville (1976), as well as the less acclaimed The Wedding (1978) and Health (1980). Short Cuts was released in 1993, but faired less well in America than in Europe where it won the Golden Lion Award for Best Film at the Venice Film Festival.

In establishing his directorial "personal stamp," Altman has often drawn on existing texts as a starting-point. ${ }^{11}$ Indeed Short Cuts, and The Player are only two of Altman's many adaptations from novels and plays. ${ }^{12}$ James Monaco goes so far as to maintain that Altman "doesn't trust himself on his own":

8 James Monaco, American Film Now: The People, The Power, The Money, The Movies, rev. edn (New York: New American Library, 1984), 3 19.

${ }^{9}$ Quoted in Ephraim Katz, The Macmillan International Film Encyclopedia, 2nd edn (London: Macmillan, I 994), 27.

10 Daniel O'Brien, Robert Altman: American Survivor (London: B. T. Batsford, I 995), i I 7.

11 André Bazin, "On the Politique des Auteurs" (1957), trans. Peter Graham, in Jim Hiller, ed., Cabiers du Cinéma: the I950s (London: Routledge, 1985), 255. Andrew Sarris argues that the auteur theory, "values the personality of the director precisely because of the barriers to its expression. It is as if a few brave spirits had managed to overcome the gravitational pull of the mass of movies," The American Cinema: Directors and Directions, 1929-1968 (New York: Dutton, i 968), 3 I.

12 See Ira Nayman's “The Adaptable Altman" for a discussion of The Long Goodbye, The Player and Short Cuts as adaptations. Creative Screenwriting, 4:3 (Autumn i 997), 84-96. 
He protects himself by playing with other people's scripts. Eventually they become very much his own movies, but this essentially reactive process allows him to add the ironic dimension that characterizes his best work: it's the basic stance of the critic, which is perhaps why he is so widely admired by film critics. ${ }^{13}$

I will consider Altman's "ironic dimension" and how he acts as a "critic" of Carver's work more fully in a moment, but this article is not simply an attempt to place Carver in the long tradition of American writers who have had a raw deal in Hollywood. As Ira Nayman points out, "adapting short stories or novels into films is a mug's game. Those who loved the book are likely to be more critical of the film version than they would of an original story. ... Those who didn't like the book, on the other hand, are not likely to be interested in a film version." 14 What I argue here is that, in the change from Carver's medium (a certain kind of short story) to Altman's (a certain kind of film), we find more than simply a formal transformation.

There are obviously very different pressures involved in the two media - unlike story-writing, film-making is " at best cooperative, and at worst a struggle," and one whose very creativity is dependant on external financial support. ${ }^{15}$ In an 1992 interview (while he was shooting Short Cuts), Altman spoke of his relationship with mainstream Hollywood:

They have not done things that I have wanted them to do, and I have not done things that they have wanted me to do. I've made enemies and I don't suffer fools gracefully. It's simply that I have an interest in doing certain kinds of work that I feel I do well and it doesn't fit in with their marketing plans, generally. So it's only occasionally that I am able to get a picture through the machinery. ${ }^{16}$

Short Cuts was one of the pictures which Altman did manage to get through the machinery - because of the success of The Player - but at the time of making the film, his position with Avenue Entertainment remained insecure. Many aspects of the film therefore seem designed to draw on the successful elements of The Player - in particular its reliance on a starry cast. (The same formula was repeated with less success in Altman's film of the Paris fashion industry, Prêt à Porter.)

But, although these factors need to be borne in mind, the point of this article is not simply to argue the limits of the auteur theory with respect

13 American Film Now, 3 I6. 14 “The Adaptable Altman," 84.

15 America in the Dark, 23 I. Tino Balio writes in the preface to a collection of essays on The American Film Industry, "No other American art form, including theater, dance, music, and fine arts, has been subjected to so many constraints, nor has any other art been influenced so heavily by the predilections of the business world," 2 nd edn (Madison: University of Wisconsin, Press, 1985), ix.

16 "Altman on Altman," ed. Graham Fuller, Projections, 2 (1993), I 59-8 I (175). 
to Altman, nor to contrast his "personal stamp" with that of Carver. Rather what I am interested in is how Carver and Altman might be seen as importantly different American artists who present radically disparate versions of contemporary America. ${ }^{17}$ A reading that conflates them is one that fails to do justice to either.

\section{“THINKING DOUBLE”}

The conflation, however, does not begin with the critics but with Altman himself. His position in relation to Carver's work was ambiguously presented in the publicity material for Short Cuts and in the interviews that he gave after its release. On the one hand, Altman attempted to distance himself from Carver, pre-empting criticisms of the adaptation by claiming, quite reasonably, that he had created a new and separate work of art. On the other hand, however, he continually evoked Carver, and spoke of "corroboration." The film was heavily marketed in relation to Carver (for example, a collection of stories used in the film - in fact taken from four separate Carver works - was produced, with a film still as its cover) and in the publicity material much was made of Tess Gallagher's involvement and approval of the film. She gave interviews with Altman and was repeatedly quoted as a source for what Ray "would have wanted."18 Moreover, she drew attention to similarities between Carver and Altman's creative approaches and thematic concerns. In her foreword to the published screenplay, for example, she writes:

On one of my last nights in L.A. at a meal at the Ganita restaurant, Altman and I had been talking about our mutual fascination with doubles, the wild probability of gaining that extra likeness which might extend your life into the secret fruitfulness of the path not taken. "Ray was a Gemini," I told Bob in my now habitual reflex of keeping Ray present in our conversations. We also spoke about poetry - Ray's love of it. I said I felt Ray's stories had the hum and leap of poetry inside them. Later, as we left the restaurant, Bob came back from the car to where I was standing with Frank at the curbside to plant a kiss on my mouth so firmly it was brotherly. "Goodnight Poet," he said, and without a beat, I answered: "Goodnight, Other Poet." Thinking double. ${ }^{19}$

17 A recent book on the director by Helene Keyssar is entitled Robert Altman's America (Oxford: Oxford University Press, I 991), while Adelman's collection of photographs claims to represent the part of America called "Carver Country."

${ }^{18}$ For example, see Robert Stewart, "Reimagining Raymond Carver on Film: A talk with Robert Altman and Tess Gallagher," The New York Times Book Review, i 2 Sept 1993, 3, 4I-42; Kitty Bowe Hearty, "Bob and Ray," Premiere (USA), 7:3 (November 1993), $58-63$.

19 Tess Gallagher, "Foreword," Robert Altman and Frank Barhydt, Short Cuts: The Screenplay (Santa Barbara: Capra Press, 1993), 7-4 (14). Gallagher and Carver shared a 
Gallagher's desire to "think double," however, extended beyond the poetic. Towards the end of Mike Kaplan and John Dorr's documentary about the filming of Short Cuts - Luck, Trust and Ketchup-Gallagher is shown offering a rather bemused Altman two of her husband's shirts, because the two men seem "about the same size."

Gallagher's search for a double for her dead husband is one thing - understandable and even touching. Altman's exploitation of this is more difficult to explain. On the one hand, it provided an opportunity for great publicity; on the other, however, it forced him into a situation in which Carver provided the agenda within which the film was discussed. ${ }^{21}$ Altman was therefore required to defend his adaptation, in particular his decision to intercut between different stories. He made two major points in his "defence." First, he claimed that by changing the structure he was preserving the spirit of Carver in a way that those adaptations which stuck closely to the letter of the texts do not. He said in interview: "I know that each story in it could make an hour or an half-hour television show, or even a full movie-of-the-week if you want to flesh it out, though then they wouldn't be Carver stories anymore. "22 What exactly Altman thinks is the "spirit" of Carver is something I will look at in a moment. Secondly, Altman argued that all of Carver's work is "just one story ... all occurences, all about things that just happen to people and cause their lives to take a turn," and his film therefore focuses on making connections and counterpoints between the different stories; what he calls "Carver soup." 23 In his introduction to the volume of Carver stories used in the

preoccupation with doubles. Gallagher's father was dying while they were working on the Dostoevsky script, and Carver notes that she gained comfort from a belief that "Dostoevsky! We're making him live again." No Heroics, Please, I I4. Carver himself thought of Chekhov as a "companion-soul" and the last story he wrote before being diagnosed with lung cancer, "Errand" (1987), was about Chekhov's death from tuberculosis. After the diagnosis, Gallagher notes, "it was to Chekhov we instinctively turned." "Introduction," in A New Path to the Waterfall (London: Collins Harvill, I989), I $3^{-25}$ (18). See Kasia Boddy, "Companion-Souls of the Short Story: Anton Chekhov and Raymond Carver," Scottish Slavonic Review, I8 (Spring 1992), 105-1 2, and Lionel Kelly, "Anton Chekhov and Raymond Carver: A Writer's Strategies of Reading," in The Yearbook of English Studies, 26 (1996), 2 I 8-3 I.

${ }^{20}$ Luck Trust and Ketchup: Robert Altman in Carver Country: The Evolution of Short Cuts, directed by Mike Kaplan and John Dorr (1993).

21 This led to statements such as "I know Ray Carver would have understood that I had to go beyond just paying tribute." "Corroborating with Carver," introduction to Raymond Carver, Short Cuts (London: Harvill Press, i 993), 7-10, (iо).

22 "Altman on Altman," I67-68.

23 Altman, "Corroborating with Carver," 7. 
film, he argued that his film "could go on for ever" and he is purportedly planning More Short Cuts. ${ }^{24}$ (He has also said that all of Poe's stories are really "one story," and more bizarrely still, "I think of Shakespeare's plays as one big piece. ${ }^{, 25}$ )

\section{"CARVER SOUP"}

Altman's decision to create connections between the stories might be placed in the context of debates about the relation between the short story, the novel and, what is seen as an intermediary form, the short-story sequence, a form that lacks the tidy coherence of the novel yet asserts some sense of connection between disparate parts. Recently some critics of Carver's work have sought to make connections between his ostensibly discrete stories, arguing that this then enables them to give a reading of the work "as a cohesive body of work." 26 For example, J. Gerald Kennedy writes of Carver's collection, Cathedral:

Like other sequences, Cathedral portrays individuals sunk in the immediacy of their own predicaments; but it also allows us to imagine encounters between characters who never meet - between the grieving parents of "A Small, Good Thing" and the obdurate father in "Feathers"; between the abandoned husband in "Fever" and the frustrated wife in "Preservation"; between the cautiously hopeful narrator of "Where I'm Calling From" and the despairing Wes of "Chef's House." Although the textual autonomy of each story precludes such interactions, the recent Robert Altman film, Short Cuts, captures just this potentiality in the tangential encounters that connect the multiple story lines developed there. ${ }^{27}$

When Raymond Carver died, his obituaries revealed how widely his achievement in the short story was recognized. Indeed, he was even dubbed the "American Chekhov." It was not unusual, however, for his obituarists" grief to extend to the fact of Carver's "failure to write a

24 Screen International reported from the 1996 Cannes Film Festival that Altman "pledged legal action against France's CiBy 2000 for breach of contract for its decision not to produce a follow-up to 1993's Short Cuts." i 7 May i996, 2.

25 Robert Stewart, "Reimagining Raymond Carver on Film: A talk with Robert Altman and Tess Gallagher," 4I.

${ }^{26}$ Review of Randolph Paul Runyon, Reading Raymond Carver (Syracuse University Press, 1992), Choice 1992. Runyon's thesis is that Carver's stories ask his readers to examine "the interstices between the stories" ( $\mathrm{I}$; his italics).

27 “From Anderson's Winesburg to Carver's Cathedral: The Short Story Sequence and the Semblance of Community," in J. Gerard Kennedy, ed., Modern American Short Story Sequences (Cambridge: Cambridge University Press, 1995), 194-215 (213). 
novel." ${ }^{28}$ Consider, for example, W. J. Weatherby, writing in The Guardian:

[Carver's] first novel was to decide how important a writer he might be. Could he carry over into a long narrative his evocation of the life of the American white working class that succeeded so well in his short stories? But he left the answer unfinished. ${ }^{29}$

The belief that Carver's status as a writer was "untested" because he had not published a novel reveals the full weight of the critical bias that exists towards the novel. The short story, it is implied, is an apprentice form, while writing a novel represents an initiation into the mature world of letters. (Hence Kennedy's suggestion that Short Cuts fulfilled Carver's "potential.") Carver's attitude to the inevitable interview question, "when are you going to write a novel?," varied depending on his selfconfidence. At times, he claimed to be working on one (the posthumous collection, No Heroics Please contains an eight page "fragment of a novel"); at other times, he forthrightly asserted that he was "happy doing what I'm doing. "'30

The introduction to Kaplan and Dorr's documentary Luck, Trust and Ketchup claims that Altman's film is an equivalent to the novel Carver "never had time to write." This alludes to Carver's often quoted account of why he wrote short stories in an essay called "Fires":

To write a novel, it seemed to me, a writer should be living in a world that makes sense, a world that a writer can believe in, draw a bead on, and then write about accurately. A world that will, for a time anyway, stay fixed in one place. Along

28 Peter Kemp, “The American Chekhov," The Sunday Times, 7 Aug. 1988, G.I-2. Miriam Marty Clark attacks what she sees as Carver's "monological imagination," and finds evidence of its existence in his "failure to write a novel." "Raymond Carver's Monological Imagination," Modern Fiction Studies, 37:2 (Summer I 99I), 240-47 (246).

29 W. J. Weatherby, "Turning Life Into Great Literature," The Guardian, 5 Aug. I 988 , 33.

30 Raymond Carver, "Fragment of a Novel - from The Augustine Notebooks," in William L. Stull, ed., No Heroics, Please, 65-72. Robert Pope and Lisa McElhinny, "Raymond Carver Speaking," in Conversations with Raymond Carver, I I-23 (I 2 ) and passim. Of course Carver was not the only short-story writer to feel the pressure to write a novel. Chekhov's correspondence, for example, reveals a continuing preoccupation with the form. After many abandoned attempts, he wrote to Suvorin that he had found his form: "What do you know? I'm writing a novel!! I am keeping at it, but can't see the end in sight. ... I have called it 'Tales from the Life of My Friends' and am writing it in the form of separate, complete stories, tightly held together by the common basis of plot, idea and characters. There is a special chapter for each story. Don't think that the novel will consist of odds and ends. No indeed. It will be a real novel, a complete whole, in which each person will be organically indispensable," Anton Chekhov, Letter to Alexei Suvorin, I I March I899, in Selected Letters, trans. Sidonie K. Lederer; ed. Lillian Hellman (London: Picador, i 984), 79-80 (79). 
with this there has to be a belief that the known world has reasons for existing, and is worth writing about, is not likely to go up in smoke in the process. This wasn't the case with the world I knew and was living in. My world was one that seemed to change gears and directions, along with its rules, every day. Time and again I reached the point where I couldn't see or plan any further ahead than the first of next month and gathering together enough money, by hook or by crook, to meet the rent and provide the children's school clothes. ${ }^{31}$

By focusing on the second part of Carver's statement, these critics ignore the first part. Carver wrote short stories not simply because he had no time to write a novel but because the short story was "demanded" by his aesthetic vision. ${ }^{32}$ Altman's making of "soup" from Carver's discrete and diverse short stories denies the importance the fragmentary form plays in Carver's work, and so inevitably results in a distortion of that work. This disturbance, moreover, is not simply formal. The change in medium is bound up with highly significant shifts in location, class and sexual politics, and it is these I will consider first.

\section{FROM "CARVER COUNTRY" TO THE CITY OF ANGELS}

Bob Adelman's Carver Country is a kind of photographic biography of Carver taking us from his childhood in Yakima in eastern Washington State through periods working in Chico, Sacramento, Palo Alto and San José in Northern California before returning to Port Angeles in Washington, where he died. In his introduction to the collection of stories used in the film, Altman defends his decision to move the stories to the L.A. suburbs:

One of the reasons we transposed the settings from the Pacific Northwest to Southern California was that we wanted to place the action in a vast suburban setting so that it would be fortuitous for the characters to meet. There were logistical considerations as well, but we wanted the linkages to be accidental. The setting is untapped Los Angeles, which is also Carver Country, not Hollywood or Beverly Hills - but Downey, Watts, Compton, Pomona, Glendale - American suburbia, the names you hear about on the freeway reports. ${ }^{33}$

If " untapped Los Angeles" is also "Carver Country," then this seems to

31 Raymond Carver, "Fires," in Fires (London: Picador, 1986), 28-39 (35).

${ }^{32}$ I am using the word "demanded" in the sense employed by William Carlos Williams in his essay "A Beginning on the Short Story (Notes)," when he notes that, when he decided to write about the effects of the Depression on the working classes of New Jersey, "the short story as a form ... [was] demanded." "The briefness of their chronicles, its brokenness and heterogeneity-isolation, color. A novel was unthinkable," Selected Essays (New York: Random House, 1954), 295-310 (300).

33 "Corroborating with Carver," 9. 
suggest that, for Altman, "Carver Country" means Anyplace-NotGlamorous, USA; what William Stull calls "Hopelessville, USA." "Tw Two questions then arise. First, is place in Carver really "anywhere" and therefore "nowhere"? And secondly, if so, is "untapped Los Angeles" also "nowhere" and "anywhere"?

To some extent, Carver's own statements support Altman's reading of the importance of place in his work. He often asserted the universality of his stories, arguing that they "could take place anywhere," since "men and women behave pretty much the same whether in Port Angeles, or Bellevue, or Houston, or Chicago or Omaha or New York City." 35 Taking this as our guide we may feel, to quote one critic, that the shift in location would not cause "too great a sense of disruption." 36

It is useful here, however, to recall what Raymond Williams says about the notion of the "regional novel." 37 Implicit in the concept of "regional," Williams argues, is the notion that while some places (the provinces) are regions, others (the urban centres) are not. Novels set in the "regions" are said to be about the places in which they are set, whereas novels set in the metropolis are thought to be about the "human condition," and setting is tangential. (Williams makes a similar point about the use of the phrase "the working-class novel," and I will return to this in a moment.) By rejecting the "regional" tag, often associated with the short story, Carver was cultivating his "universality." "38 Nevertheless, while his stories are set in a wide range of places, and, as he notes, often entirely indoors, these places are not the metropolitan centres of America. As the poem "Lemonade" (which Altman claimed serves as a thematic cue for his film) puts it:

it's a small town, this town, a small world here ${ }^{39}$

that Carver's characters inhabit, a world whose grotesques are in the tradition of Sherwood Anderson's Winsburg, Obio (1919) rather than

34 William L. Stull, "Beyond Hopelessville: Another Side of Raymond Carver," Philological Quarterly (Winter I985), I-I5 (2).

${ }^{35}$ Nicholas O'Connell, "Raymond Carver," in Conversations with Raymond Carver, 50-5 I.

36 Adam Meyer, Raymond Carver (New York: Twayne, I995), I72, fn. 3.

37 Raymond Williams, "Region and Class in the Novel," in Writing in Society (London: Verso, I98 I), 229-38. See also Eric Sundquist, "Realism and Regionalism," in Emory Elliott, ed., The Columbia Literary History of the United States (New York: Columbia University Press, I988), 503.

38 On the short story and regionalism, see Sandra A. Zagarell, "Narratives of Community: The Identification of a Genre," Signs, I3:3 (Spring I 988), 498-527.

${ }^{39}$ Carver, Short Cuts, i 55-57 (155). All further page references to this collection will be cited in the main text. 
Nathaniel West's The Day of the Locust (1939). ${ }^{40}$ Secondly, and perhaps more importantly, these places are all impermanent, temporary. Wherever the characters are, they are always dreaming of being elsewhere, aspiring to a better life. Looking closely at the stories that make up Short Cuts we get a different picture. Since my argument here is that we should not reduce these stories to a soup-like substance, I will consider them in the order they appear in Altman's collection. ${ }^{41}$

While there is no named setting in "Neighbors," it is a kind of travel story between apartments - the Stones have gone "to Cheyenne, then on to St. Louis to visit relatives"; their neighbours, the Millers, cannot afford to go away, so they go next door. In "They're Not Your Husband” there is again no named setting, but Earl spends most of the story travelling around for job interviews. Place features more precisely in "Vitamins," certainly in conversations - the narrator and his wife, Patti, "got to talking about how we'd be better off if we moved to Arizona, someplace like that" (p. 33), while, later on in the story, Patti's friend (and his oneoff date), Donna, wonders about going to Portland.

"Maybe I could go up to Portland," she said. "There must be something in Portland. Portland's on everybody's mind these days. Portland's a drawing card. Portland this, Portland that. Portland's as good a place as any. It's all the same." (p. 44)

"Will You Please Be Quiet, Please?" is set in Eureka, CA. Ralph and Marian go to Guadalajara on their honeymoon, but Ralph finds the "squalor and open lust" of the place disturbing, and wants to return to "the safety of California" (p. 48). In "So Much Water So Close To Home" Stuart goes fishing with some other men in the Naches river in Washington State. Later as his wife reflects on the fact that the men have left a dead girl floating for days while they fished, she drives past the local Everson Creek. "So much water so close to home, why did he have to go miles away to fish?" she thinks (p. 76). In "A Small, Good Thing," no place is named. The story moves between the home, the hospital and the bakery. "Jerry and Molly and Sam" begins with Al's feeling that "nothing was going right lately" and his decision to get rid of the dog,

40 The Day of the Locust has spawned a tradition of Los Angeles apocalyptic fiction, a recent example of which is Brett Easton Ellis's Less Than Zero (1985).

41 The stories were taken from several collections. "Neighbors," "They're not your husband," "Will you please be quiet, please?," "Collectors" and "Jerry and Molly and Sam" were first published in Will You Please Be Quiet, Please? (New York: McGraw-Hill, 1976). "Tell the Women We're Going” was published in What We Talk About When We Talk, About Love (New York: Knopf, i98 I). "So much Water so Close to Home" was first published (in this version) in Fires (Santa Barbara: Capra, I 983 ). 
Suzy. In the film, this is just presented as an unexplained frustration of an unpleasant man. Gene (played by Tim Robbins) works as a motorcycle cop. In the story, however, $\mathrm{Al}$ is unemployed, and his frustration stems from that. To add to his troubles, his wife had persuaded him, "just before all the layoffs began," to move to a "cushy two-hundred-a-month place. Lease with an option to buy" (p. I 23). Thinking about what a mess his life is, and deciding "he had to start someplace - setting things in order, sorting all this out," he takes the dog to dump it back near their old home. Going there, however, does not have the restorative effect he anticipated.

He cruised along, and when he came to his old house he slowed down almost to a stop and stared at the front door, the porch, the lighted windows. He felt even more insubstantial looking at the house. He had lived there - how long? A year, sixteen months? Before that Chico, Red Bluff, Tacoma, Portland - where he'd met Betty - Yakima ... Toppenish, where he was born and went to high school. (p. 128$)^{42}$

While $\mathrm{Al}$ moves around a lot without seeming to go anywhere, the narrator of "Collectors" is completely grounded in his own house. Indeed he lies on the couch all day waiting for news of a job "up north" - "I'm going to be leaving here soon" (p. I45) - and, unlike everyone in Altman's film of the L.A. freeways, has no car. As Baudrillard points out, disenfranchisement is, for many Americans, represented by the loss of "first your job, then your car. And when your driver's license goes, so does your identity." Going" still have cars. Leaving their wives, with the feeling that "Guy's gotta get out" (p. I49), they head out to drink and play pool. They pick up two girls who say they're going "no place," and offer to take them to Picture Rock. Before they get there, and before Jerry - the loud-mouthed one, not the repressed one - kills the girl, they pass a fork in the highway. "The highway forked here at Picture Rock, one road going on to Yakima, the other heading for Naches, Enumclaw, the Chinook Pass, Seattle" (p. is 2).

The only moment that feelings of entrapment and the desire to escape are expressed in Short Cuts is towards the end when Earl (Tom Waits) and

42 Like Al, Raymond Carver lived in small towns all over the States. For example, during the sixties and seventies he lived in the following towns in California: 1960, Eureka; 1961-63, Arcata; 1964-66, Sacramento; 1967, Palo Alto; 1968-69, Hollywood; i 969, San José; 1970, Sunnyvale; 1971, Ben Lomond; 1972-76, Cupertino.

43 Jean Baudrillard, America, trans. by Chris Turner (London: Verso, i 988 ), I I 2. See also Carver's poem "The Car," in In a Marine Light: Selected Poems (London: Collins Harvill, I987), 44-45. 
Doreen (Lily Tomlin) dance a conga singing "Gettin' outta Downey"; ${ }^{44}$ otherwise, there is no suggestion that everyone has not always been and will not always be in their not uncomfortable suburban homes. Terrible and arbitrary things may happen to them, but they stay put. Indeed there is nowhere else to go-L.A. is the end of the line, "the last American frontier." 45

The second question that I raised concerning setting is whether Los Angeles, "untapped" or not, can ever be a neutral setting. As Michael Sorkin (echoing many others) put it, "L.A. is probably the most mediated town in America, nearly unviewable save through the fictive scrim of its mythologizers." 46 Mike Davis argues what he calls a "dialectic of sunshine and noir" (or American dream and nightmare) exists in writings about the city, and argues that for this reason L.A. has attracted critics and writers looking for the "pure America." 47 Despite Altman's claim that he is not dealing with "Hollywood or Beverley Hills," everything in the film, as Michael Woods points out, "has Hollywood written all over it." 48 Its influence remains particularly in the jobs and concerns of the characters. Tess, the jazz torch song singer invented wholly by Altman and Barhydt, says at one point, "I hate L.A. All they do is snort coke and talk." ${ }^{49}$ No one is seen snorting in the film, but their frantic behaviour and talk suggests that atmosphere. Carver Country is not frenetic like L.A. - in fact no one talks much at all.

And what could be more distinctly Californian than the earthquake which ends the film? - in particular the way it is used as the great Californian unifier, even if not the Big One. ${ }^{50}$ The film ends with the pilot who had flown over the city in the opening shots describing what he had seen during the earthquake. "As I was landing I was thinking to myself what a beautiful sight L.A. is. ... It is a beautiful day, the kind of day every

44 Short Cuts: The Screenplay, 123.

45 Alison Lurie, The Nowhere City (1965) (Harmondsworth: Penguin, 1977), 31.

${ }^{46}$ Michael Sorkin, quoted in Mike Davis, City of Quartz: Excavating in Los Angeles (London: Verso, I990), 20.

47 City of Quartz, 23, 48.

48 Michael Wood, "Why the birthday party didn't happen," London Review of Books, ro Mar. 1994, I9.

49 Short Cuts: The Screenplay, 96.

50 Jonathan Romney says of the fact that the earthquake erupts at the very second Jerry smashes a rock on the girl's head, "Perhaps Jerry's pent-up rage is the entire city's." "In the Time of Earthquakes," Sight and Sound (Mar. I994), 8-I I (9). Romney's comment is echoed by David Reid in the preface to the paperback edition of Sex, Death and God in L. A. Short Cuts was released in the States at a moment when perceptions of L.A. as apocalyptic had reached a new peak. Coming in the wake of the trials of the policemen who had beaten Rodney King, and numerous local brush fires, Reid describes it as "the emblematic L.A. movie of the season." Sex, Death and God in L.A. (Berkeley: University of California Press, i 994), ix-xxix (xii). 
Angelino says to himself or herself just how lucky he or she is to be living in L.A." $" 51$ The camera then pans over the cityscape. The film's working title was L.A. Short Cuts and it remains an L.A. movie. ${ }^{52}$

\section{"THIS CLASS THING"}

Linked to the change in setting are changes in the class of the characters. Altman's characters are middle or upper middle-class suburbanites, while Carver's are working class, or lower middle class. "I write," he once said, "about working-class people, and the dark side of Reagan's America. ... the stories can be read as a criticism, as an indictment." 53 According to Altman, "in the way that I'm retelling Ray Carver this class thing is not necessarily an element that is making things happen. ... To do a whole thing about people who are out of work would give some sort of meaning to this picture that I didn't want to give to it."54 As Raymond Williams points out, the idea of class is commonly used in a very similar way to that of region - as "a social area inhabited by people of a certain kind, living in certain ways." "55 We can have a "working-class story" therefore, but middle-class fiction is somehow "universal." Once again then Altman is doing Carver the unasked for "favour" of "universalising" his work.

In Short Cuts, there is only one unemployed character, Stuart, the fisherman, and this fact is mentioned only very briefly and late on in the film. I have already mentioned "Jerry, Molly and Sam," but unemployment is at the heart of many of these stories of the I970s recession, the spur to crises in the lives of many Carver characters. Earl works as a limousine driver in the film; in "They're Not Your Husband" he is unemployed, "between jobs as a salesman." Feeling his own life slipping from his control, Earl takes charge of his wife's. He puts her on a strict diet, and monitors the response of her (and now his) "customers" at the coffee shop, revived by finding himself again a salesman. Meanwhile "Collectors" begins:

51 Short Cuts: The Screenplay, I 3 I.

${ }^{52}$ Charles Deemer goes further and argues that "the landscape of Southern California ... becomes a central character in the film." "Short Cuts: The Los Angelesation of Raymond Carver," Creative Screenwriting, 4:3 (Fall I997), I I-I 7 (I I). David Thomson maintains that Short Cuts "caught the hazy, slippery looseness of L.A., its casual violence, and its childishness with a precision seldom attempted by mainstream Hollywood." "Robert Altman," in The Biographical Dictionary of Film, rev. edn (London: Andre Deutsch, i 994), 9-1 I (I I).

53 Boddy, "A Conversation," $20 \mathrm{I}$.

${ }^{54}$ Stewart, "Reimagining Raymond Carver on Film: A talk with Robert Altman and Tess Gallagher," 4I. $\quad{ }_{55}$ Williams, "Region and Class in the Novel," 234. 
I was out of work. But any day I expected to hear from up north. I lay on the sofa and listened to the rain. Now and then I'd lift up and look through the curtain for the mailman. (p. I38)

The narrator's day is disturbed by a vacuum cleaner salesman who inexplicably steals his mail (perhaps the letter that is offering him a job).

But Altman is not interested in the tediously anxious life of the unemployed and the poor. He is interested, he says, in "the wonderful idiosyncrasies of human life" and the Hollywood effect is also present here - not only in the two characters Altman invents, Tess, the torch song singer and Zoe, her cellist daughter. Carver's characters are also given more glamorous, more "idiosyncratic" lives. In the Altman version of "Collectors," Stormy Weathers is not unemployed and on the couch but a pilot, sawing his wife's furniture into pieces when the salesman arrives, does his demo and leaves. In "Neighbors" Bill is a machine-parts salesman; in the film he is studying to be a make-up artist and he woos the girls from "Tell the Women We're Going" by pretending to be a talent scout. Patti in the Carver story sells vitamins, in the Altman version she sells telephone sex; in "Will You Please Be Quiet, Please?," Ralph and Marian Wyman are not a doctor and an artist but high-school teachers; Howard Weis is a junior partner in an investment firm in the Carver story - he becomes a TV presenter in Altman's film.

To live in "untapped Los Angeles" is still, as David Thomson puts it, "to be within the most futile reach of The Story, The Show."

It is grisly yet lulling that the waiters in L.A. are waiting to be actors, that valet parking attendants have script projects, and that the kids in the mail room have board-game plans for taking over the studio. There is so much scrambling, smiling readiness to be convincing. People in L.A. think in scenes and give you lines; the city is like a daytime talk-show. ${ }^{56}$

The fact that we see such stars as Robert Downey, Jr., Tim Robbins, Jennifer Jason Leigh, Jack Lemmon and Andie McDowell living "within the most futile reach" of Hollywood proper, adds another dimension to Altman's ironic view of the film capital. ${ }^{57}$ It has nothing, however, to do with the suburban life of "untapped Los Angeles."

${ }^{56}$ David Thomson, "Uneasy Street," in Reid, ed., Sex, Death and God in L.A., $32 \mathrm{I}^{-} 33$ (327).

${ }^{57}$ For Jonathan Romney, "as a variation on the old life-as-movie metaphor, it's infinitely more interesting than his much more overt The Player." "Short Cuts," New Statesman and Society, i I Mar. I 994, reprinted in Short Orders: Film Writing (London: Serpent's Tail, I 997), IоI-04 (103). 
A fear of sounding like a participant in a daytime talk-show bothers many of Carver's characters. Picturing themselves as the heroes of Bmovies or the heroines of song-lyric clichés, they frequently succumb to what one critic describes as "the attrition of the person by junk language," but, unlike Altman's characters, they are aware of the process and unhappy about it. ${ }^{58}$ In " A Small, Good Thing." Howard's wife Ann (played by Andie McDowell in the movie) recognises this phenomenon in her own speech. As she leaves the hospital where her son has just died, she "'began shaking her head. 'No, no,' she said. 'I can't leave him here, no.'”

She heard herself say that and thought how unfair it was that the only words that came out were the sort of words used on TV shows where people were stunned by violent or sudden deaths. She wanted her words to be her own. (p. I I4)

Although Carver was championed as "the poet of inarticulacy," he argued that, while his characters have problems being able to "talk and say what they really mean," "there are other ways of communicating." 59 The feelings that cannot be expressed in words are expressed in gestures, and in silence. This is something that Altman never explores. No one in the film is ever at a loss for words.

\section{DOING "THE RIGHT THING"}

Ignoring or simplifying many of the concerns that I have just outlined - questions of class, place, communication - Short Cuts focuses on one aspect of Carver's fiction - sexuality, and in particular it foregrounds the sexual violence which usually remains a latent tension in the stories. ${ }^{60}$ Almost all the stories in the film are in some way about sexual frustration, and at the film's climax these are released.

In Short Cuts, Sherri poses nude for her painter sister Marion. Marion's husband watches and later confronts his wife about an adulterous incident. She spills wine on her dress and takes it off to clean it. For some reason she is not wearing any underwear. Meanwhile Sherri goes home and tells her husband, the philandering Gene, that Ralph has seen her nude. This excites him and they have sex. In another house, Lois, a telephone sex salesgirl, won't talk dirty to her own husband. Frustrated,

58 Alain Arias-Misson, “Absent Talkers,” Partisan Review, 49:2 (Winter 1982), 625-28 (626).

59 Adam Mars-Jones, "Words for the Walking Wounded," Times Literary Supplement, 22 Jan. 1982, 76; Boddy, "A Conversation," 200.

${ }^{60}$ Nick Hornby's suggestion that Carver's stories are "curiously sexless" seems equally flawed. Contemporary American Fiction (London: Vision Press, i 992), I 53. 
he eventually slams a rock on a girl hiker. His friend Bill makes up his wife to look battered and photographs her, then wonders why this excites him. His photos are subsequently muddled up with those of the naked dead girl taken by one of the fishermen.

If Altman is making a point, he makes it again and again, and we are tempted to follow Ralph when he challenges Marion about her paintings, asking "Why does naked make it art?"61 The question itself echoes feminist criticisms of the infamous "Hotlips-in-the-shower" scene in Altman's 1970 film $M^{*} A^{*} S^{*} H$, a Vietnam film about the Korean war. Short Cuts may seem far from the battle zone, but, curiously, Altman's version of "the war of the sexes" constantly refers to other wars. The film opens with images of helicopters, self-consciously evoking Altman's previous productions, the TV show Whirlybirds and $M^{*} A^{*} S^{*} H$, as well as Apocalypse Now. Stormy Weathers (Peter Gallagher), the pilot, talks of "Bombin' the dirty medflies" (albeit with Malathion rather than Napalm). In case we have missed the allusions, Howard, the TV commentator, tells us that "this is war." And later Howard asks Jerry, the pool attendant, "how goes the war?" "Bad guys are winning, sir," Jerry replies. The policeman's son continually wields a toy gun and says "Bang Bang." Life in Altman's L.A. is a series of daily battles, and the war begins at home.

Despite Altman's insistence on violence and explicit sexual language at every turn, his exploration of sexuality is, however, ultimately a sanitised version of Carver's. In "Vitamins," as I mentioned, Patti sells vitamins door to door, while her counterpart in the film, Lois, sells sex on the phone from home. Of the shift from vitamins to sex, Gallagher has said that what Altman does, "is move Ray's vision into the time in which we are living, the 90's." "62 It certainly increases the voyeuristic aspect of the film - both for Lois's husband, Jerry, and for the viewer. In the original story, however, the husband becomes jealous and anxious, not because she sells sex, but because another woman is in love with his wife. The husband does not kill his rival-she goes to Portland-instead he attempts an affair with another of his wife's friends, but it all goes wrong when she, in turn, is propositioned in a bar by a Vietnam veteran who shows her the ear of a man he has killed. She takes this as a sign that she should leave town and go to Portland too.

And consider "Neighbors." In Short Cuts, the husband simply suggests to his wife that they "do the right thing in their [the neighbours'] bed." ${ }^{63}$

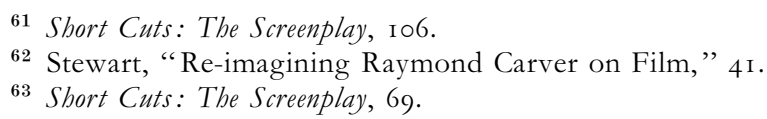


In the story, Bill goes over there on his own, masturbates for a while in the bed, then tries on Mr. Stone's Hawaian shirt followed by Mrs. Stone's panties and bra.

He stepped into the panties and fastened the brassiere, then looked through the closet for an outfit. He puts on a black and white checkered skirt and tried to zip it up. He put on a burgandy blouse that buttoned up the front. He considered her shoes, but understood they would not fit. For a long time he looked out the living-room window from behind the curtain. Then he returned to the bedroom and put everything away. (pp. 17-18)

Altman's version is again much tamer, much more conventional, and perhaps, therefore, more marketably "9os."

What is most disturbing about these shifts in the representation of sexuality is that, whereas Carver, in discrete stories, explores both male and female perspectives - sometimes with a distancing ironic commentary ("Will You Please Be Quiet, Please?") but most often with compassion and sympathy (for example, "So Much Water" is told entirely from the wife's point of view, "Jerry and Molly and Sam" from the husband's) Altman's film, committed to the idea that "it is all one story," provides only one perspective - the all-seeing, all-knowing directorial point of view; one that focuses on a particular brand of frustrated male aggression, and one which does not allow any interior life to his characters. ${ }^{64}$

\section{"WHAT CONNEXION CAN THERE BE ...?"}

Despite Altman's repeated assertions that it was the randomness and arbitrariness of Carver's world with which he felt affinity, the world of Short Cuts is neither random nor arbitrary. His characters may not know what will happen next, but Altman certainly does. His presence as the controller and particularly the integrator of the stories and lives he describes is continually felt. This is particularly true of the way the film depends on frequent rapid cutting between different images for counterpoint effects. TV images are particularly useful for this. For example, while Doreen tells Earle about hitting the child, Casey, with her car, a bowling ball whacks into skittles on the TV screen. And, when Ann offers the already comatose Casey a glass of milk, the camera zooms in on the glass of milk then cuts to a TV in another house which shows a glass of milk being knocked over and spilling on the floor. The announcer comments: "ACCIDENTS HAPPEN EVERY DAY. Fortunately most are

${ }^{64}$ David Thomson notes Altman's "squeamishness about people." "Robert Altman," I I . 
harmless, but some are very serious." Later we see Zoe the cellist floating naked and as if dead in her pool, and then Altman cuts to the dead girl's body in the river. As Eisenstein said in I94 I, while "shooting in long take is almost always neutral and passive," rapid cutting and montage are "above all ... active ... [forms] of narrative." "65

Altman also uses more sustained forms of what he calls the film's "connective tissue" - Howard's TV editorials and Annie Ross's songs (particularly the recurring "Prisoner of Life") provide a choric effect. The film connects the characters at the beginning with the fleet of helicopters flying and spraying anti-medfly insecticide over all (a unifying device that recalls Virginia Woolf's sky-writing plane in Mrs Dalloway) and, at the end, with the earthquake that again touches everyone. ${ }^{66}$ The characters also connect up in quite straightforward ways. For example, the doctor from one story treats the child from another. His wife's sister features in yet another story, while his father reappears to tell his own. It does not seem fortuitous that all these characters meet up - many of them are related, the others work in various kinds of service industries - as a waitress, a doctor, a policeman, a musician. In the light of all this, it is strange to read praise for Short Cuts's depiction of the "anonymity" of Los Angeles life. ${ }^{67}$

In many ways, then, Altman's handling of plot and character is more reminiscent of Dickens (and his filmic protegés, Eisenstein and D. W. Griffith) than Carver. Consider this famous passage from Bleak. House:

What connexion can there be, between the place in Lincolnshire, the house in town, the Mercury in power, and the whereabout of Jo the outlaw with the broom, who had a distant ray of light upon him when he swept the churchyardstep? What connexion can there be between many people in the innumerable histories of this world, who, from opposite sides of great gulfs, have nevertheless, been very consciously brought together!

Jo sweeps his crossing all day long, unconscious of the link, if any link there be. He sums up his mental condition, when asked a question, by replying that he "don't know nothink."

Jo may not know much but Dickens certainly does. Moreover he does not simply spot connections that his characters fail to perceive - he creates

${ }^{65}$ S. M. Eisenstein, On the Composition of the Short Fiction Scenario, trans. Alan Upchurch (London: Methuen, I984), I0. I disagree with Helene Keyssar's assertion that "Altman's montage is rarely didactic," Robert Altman's America, i 36.

${ }^{66}$ Virginia Woolf, Mrs Dalloway (1925). "Suddenly Mrs Coates looked up into the sky. ... Everyone looked up," (Harmondsworth: Penguin, I992), 2 I-22. See also Elaine Showalter, "Introduction," xxi-xxiii. $\quad{ }^{67}$ Romney, "Short Cuts," 103.

${ }^{68}$ Charles Dickens, Bleak House (1853), Ch. I6 (Harmondsworth: Penguin, I985), 272. 
and organises the world in which those connections exist. ${ }^{69}$ If we think about what this Dickensian sweep means in the American context, it does not take long to reach the idea of the Great American Novel, which in film becomes something like Short Cuts or Nashville. ${ }^{70}$

Nashville (1975)-still Altman's most acclaimed film - is about one weekend in the lives of twenty-four people in Nashville, Tennessee. The film uses many of the same techniques as Short Cuts - rapid intercutting and a continuously moving camera present a barrage of sensory impressions, characters talk and overlap each other, while music provides a choric commentary. As its screenwriter, Joan Tewksbury, put it: "Everything had whirled and spun and played upon your senses." The first shot introduces the election campaign van of the presidential candidate, Hal Philip Walker, calling on "Fellow taxpayers and stockholders of America," and the van recurs through the film, until the characters all gather together for the political rally which forms the film's finale, when, in a shock ending, a demented gunman kills one person and wounds another.

Nashville is quite consciously a "state of the nation" movie, an epic for the bicentennial. L.A. Short Cuts has similar ambitions. Altman strips Carver's America of class, history and difference, and unifies it as a place of luck, sex, violence and TV. Apocalyptic America, in other words, is once again pictured in terms of the entertainment industry - in Nashville, it was country music; in Short Cuts, it is Hollywood, imagined as it was in Nathaniel West's novel, as both "dream factory" and "dream dump. "71

In Gravity's Rainbow, Thomas Pynchon famously distinguished paranoia - where everything connects - from anti-paranoia - "where nothing is connected to anything, a condition not many of us can bear for long." These two opposing impulses might also be said to characterise the work

69 According to Ray Carney, “Altman's characters are never completely empowered. From Nashville to The Player, they more or less operate as semiotic functions of the structures placed around them," The Films of John Cassavettes: Pragmatism, Modernism and the Movies (Cambridge: Cambridge University Press, 1994), I4I.

${ }^{70}$ Ira Nayman argues that, because in the movie we see the characters in more than the "one context" the short story supplies, "Altman's film offers a more complex view of life than Carver's original stories," "The Adaptable Altman," 90. Keyssar describes Altman's vision as "Whitmanesque," Robert Altman's America, i 5 I.

71 James Monaco writes, "Altman's people are universally addicted to an American mythos, propagated by the media, not least of all film, to which their own reality never measures up. Altman doesn't seem to want to let them take action, and that is a major and unavoidable criticism of the theory of his work," American Film Now, 326.

72 Thomas Pynchon, Gravity's Rainbow (London: Picador, i975), i 88, 434. 
of Altman and Carver respectively. Altman's desire, in film after film, is to create systems (American microcosms) within which his characters are contained and constrained. Carver's desire, in story after story, is to write about individuals who, like Hawthorne's Wakefield, "step aside for a moment" and expose themselves to "the fearful risk of losing ... [their] place forever." 73

To find the filmic equivalent of Carver one could do worse than to go back to the seventies (indeed, to when these stories were written) and to another director who operated on the margins of the Hollywood studios, John Cassavettes. Cassavettes's A Woman Under the Influence (filmed in 1972, released in 1974) presents only one story - of a hard-to-understand family dynamic, in which everyone finds it hard to communicate how they feel or who they are. The husband, Nick's (Peter Falk) misguided attempts to look after his family and his obsession with control, the non sequitars, the uncomfortable eccentricity of conversations and the banal yet touching scene with which the film finishes, in which the husband and wife, after terrible rows, slowly and silently clear the table and make up their bed for the night, could be said to be much closer to the "spirit" of Carver than anything in Short Cuts. $^{74}$

Ironically, Altman's vision of America is much bleaker - much more cynical and apocalyptic - than that of either Cassavettes or Carver. Not only does life in "untapped Los Angeles" seem sown up, but, as viewers, we leave the cinema with no doubt as to what we are supposed to think. ("You may say / That I aint free / But it don't worry me," runs the final song in Nashville). Carver's stories, on the other hand, leave individual fates largely undecided and plenty of space for the reader. In Roland Barthes's terms, Cassavettes and Carver are writerly, Altman readerly. ${ }^{75}$ While Altman's cutting and montage lead the viewer "along the necessary

${ }^{73}$ Nathaniel Hawthorne, "Wakefield," in Tales and Sketches (New York: The Library of America, I982), 90-98 (298).

${ }^{74}$ Charles Deemer offers John Huston's 1972 adaptation of Leonard Gardner's novel of down-at-heel boxers, Fat City as the film that he thinks has the "feel" of Carver. "Short Cuts: The Los Angelesation of Raymond Carver," I 7. James Monaco notes that $A W$ oman Under the Influence was Cassavettes" "most widely seen and most financially remunerative" film. Monaco compares Cassavettes's films to Chekhov's plays, and we could extend the comparison to Carver's stories: all "are about rather sad people - losers, if you like - who don't ever seem to get anywhere, but who enthrall audiences with their inaction, their self-centredness, and their cosmically funny failures. ... They take place almost exclusively in interiors." Of Cassavettes' characters, he adds, "sometimes you wish they could at least spend a holiday in a Robert Altman movie," American Film Now, 299, 300, 304.

75 Roland Barthes, S/Z (1970), trans. Richard Miller (Oxford University Press, I 990). 
sequence of vision," AWoman Under the Influence is shot entirely in long take. And, as Eisenstein says,

If you present ... [something] in a single long take, then the viewer will begin looking at what took place. You permit him, as in life, to select details himself and focus his attention on what be wants, not what you want to show. ${ }^{76}$

Thematically, too, Carver and Cassavettes leave things open. In Carver's writing, events that should change everything-infidelity, betrayal, violence-often do not change anything. In the poem, "Miracle," for example, a woman, unable "to take any more," beats up her husband as they fly from Los Angeles to San Francisco. Once again, the idea of a single straightforward cause is undermined:

It could have been the accumulation of the day's events, or years on years of failure and corruption that triggered the violence.

But after it is over, he "picks up / his drink almost as if nothing's happened / although it has of course."77 Similarly, in A Woman Under the Influence, after Mabel (Gina Rowlands) returns to her family after being sectioned to a psychiatric hospital by her husband, nothing much seems to have changed. She still seems crazily unpredictable, their lives still seem difficult. We do not know what will happen next.

Characters in a Carver story or a Cassavettes film have too much trouble "drawing a bead" on their own lives to take on the burden of some abstract entity called "society" or "America," yet ultimately their very scepticism about wider social contexts and their belief in the power of individual endurance are also very American. Once again it seems, system and anti-system, paranoia and anti-paranoia, form two sides of the American coin.

${ }^{76}$ Eisenstein, On the Composition of the Short Fiction Scenario, Io.

77 Raymond Carver, "Miracle," in A New Path to the Waterfall (London: Collins Harvill, I989), 58-62. 